\title{
PRELIMINARY DESIGN FOR A JET TRAINING AIRCRAFT
}

\author{
Vasyl Loginov ${ }^{1^{*}}$ (D) 0000-0003-4915-7407 \\ Oleksandr Grebenikov ${ }^{2}$ (D) 0000-0002-1509-0665 \\ Andrii Humennyi ${ }^{2}$ (D) 0000-0003-1020-6304 \\ Serhii Eremenko ${ }^{2}$ (D) 0000-0002-5107-4718 \\ Oleksandr Soboliev ${ }^{2}$ (D) 0000-0002-2151-003X \\ ${ }^{1}$ JSC FED, 132 Sumska Str., Kharkiv, 61023, Ukraine \\ ${ }^{2}$ Kharkiv Aviation Institute - National Aerospace University, 17 Chkalov Str., Kharkiv, 61070, Ukraine \\ *login_w@ukr.net
}

\begin{abstract}
This paper present the results of our project to develop the preliminary design of a jet trainer plane (JTP) with a two-person crew, the base version of which is intended for cadet training. We first consider the assumptions and requirements for the new aircraft, and review the parameters of existing aircraft designs in the similarly-purposed class. Next we argue for certain design choices, regarding the aircraft layout, cockpit configuration, wing location and wingform, tail scheme, and powerplant. The resulting aircraft design is calculated to have a maximum flight speed of $940 \mathrm{~km} / \mathrm{h}$, a ground-level rate of climb of $100 \mathrm{~m} / \mathrm{s}$, and a range of $1130 \mathrm{~km}$. The plane's take-off mass is calculated, in three approximations, at $2264 \mathrm{~kg}$. Lastly we present the training plane's geometrical parameters, general view, and master geometry.

Keywords: jet trainer plane, performance, take-off mass, scheme, master geometry

Type of the work: Case Study

\section{INTRODUCTION}

Mastering the ability to fly a complex airplane of the new generation requires a multi-stage training system, at the initial stage of which future pilots generally acquire basic piloting skills. The initial training of flight crews often takes place in light, double-seat aircraft. A new jet training aircraft (JTA) of this type, offering good dynamic and maneuverability characteristics, would improve the level of flight training of cadets, and thereby the professional level of flight crews. In the design and development of such a JTA, the needs of customers should be taken into account, and domestic components, such as engines and instruments, should be harnessed in order to significantly reduce the cost of production. The production of such a new training aircraft can therefore be a source of orders for the domestic (in our case, Ukrainian) aviation industry.
\end{abstract}




\section{LITERATURE REVIEW AND PROBLEM STATEMENT}

Under the statistical design method, the parameters of a new aircraft type are estimated by comparing them to the statistical data of similarly-purposed aircraft. This design method also involves selecting flight data and relative parameters of the designed aircraft by extrapolating their possible advancement over the coming years, so that by the time a new aircraft model is released it will not be out of date [1].

The method of optimal aircraft design began to develop with attempts to analytically solve problems of selecting the most favorable aircraft parameters, taking into account the relationships between those parameters and the aircraft's flight characteristics. This method is based on the engineering search for aircraft parameters and characteristics that best meet the selected efficiency criterion [1].

The aircraft designer V. Bolkhovitinov showed how components of weight could be expressed by means of flight characteristics and design parameters in the equation of an aircraft's mass balance. The transformed equation allows one to establish not only connections between various characteristics and parameters of the plane, but also the possibilities for the realization of these properties given the contemporary level of advancement of aviation science and technology. The efficiency of an aircraft can be determined by the level of weight perfection of the aircraft as a whole and its units [1].

Methods for the general design of airplanes can be found, for instance, in [1, 2, 5]; however, features of designing a modern JTA are not quite accurately disclosed. Practice has shown that the main characteristics of a training aircraft should be survival on the ground and in the air, maneuverability, as well as the ability to effectively support training of close air combat $[3,8]$.

The JTA aircraft presented herein is intended to serve as the basis of a maneuverable aircraft family, with two crewmembers and one AI-222 turbojet engine. In general, the designed aircraft must provide: - a wide range of functionality in terms of speed and altitude, with maximum flight speed of not less than $940 \mathrm{~km} / \mathrm{h}$, maximum flight altitude of not less than $15000 \mathrm{~m}$;

- high maneuverability $\left(m_{z}^{c_{y}}=-(0.03 \ldots 0.05)\right)$;

- short running distance: run length of no more than $250 \mathrm{~m}$;

- modern level of technical and operational perfection;

- compliance with modern airworthiness standards (AP-23 - acrobatic aircraft) and quality standards.

The basic JTA is expected to replace obsolete training aircraft.

Further design assumptions were as follows:

1. The purpose of the aircraft

The JTA aircraft is designed to be used to train cadets and maintain flight skills.

2. General requirements

The aircraft, its engines, equipment and other components, as well as operating documentation must comply with aviation regulations (AP-23).

Aircraft flight and engineering training programs must be developed prior to the completion of certified tests.

In order to control the correctness of the specified flight modes and the piloting technique, to assess the professional level of pilots, and evaluate the technical condition of the aircraft, in the process of developing airframe durability its equipment and functional control systems should provide for the processing and analysis of flight information using a ground-based system personal computer.

3. The aircraft is designed to be flown:

- according to the rules for visual flight and instrument-based flight;

- in simple and difficult meteorological conditions, in conditions of icing;

- at day and at night;

- over plains and mountain surfaces;

- above water areas, up to 30 minutes away from land. 
Durability and service life:

a) aircraft (to deposition):

landings $\quad-30000$;

flight hours - 10000 ;

service life -15 years;

b) engine: full designated $\quad-5000$ hours;

c) components, as a rule, must have a service life corresponding to that of the aircraft itself, or corresponding to a multiple of anticipated maintenance periods.

4. Performance requirements:

\begin{tabular}{ll}
\hline Load weight & $-240 \mathrm{~kg} ;$ \\
Maximum flight speed & $-940 \mathrm{~km} / \mathrm{h} ;$ \\
Cruising speed & $-850 \mathrm{~km} / \mathrm{h} ;$ \\
Cruising altitude & $-11000 \mathrm{~m} ;$ \\
Range & $-1130 \mathrm{~km} ;$ \\
Take-off length & $-250 \mathrm{~m} ;$ \\
Ground-level rate of climb & $-100 \mathrm{~m} / \mathrm{s} ;$ \\
Maximum overload & $-+8 \mathrm{~g},-4 \mathrm{~g}$.
\end{tabular}

\section{THE AIM AND OBJECTIVES OF RESEARCH}

The purpose of this study is to develop a preliminary design of for jet training aircraft (JTA) satisfying the above assumptions and requirements.

\section{STATISTICAL REVIEW OF SIMILAR DESIGNS}

Based on the basic requirements for the designed aircraft, the statistical data of various aircraft considered to be in the same class were analyzed [9]. These craft are listed as follows, and the results of the statistical data processing are given in Tab. 1. The main values of the geometric parameters of JTA are shown in Tab. 2.

ATG Javelin - a two-seat aircraft equipped with two jet engines (Fig. 1), developed by the Aviation Technology Group (ATG) for a wide range of uses, such as charter flights, air taxis, flight crew training.
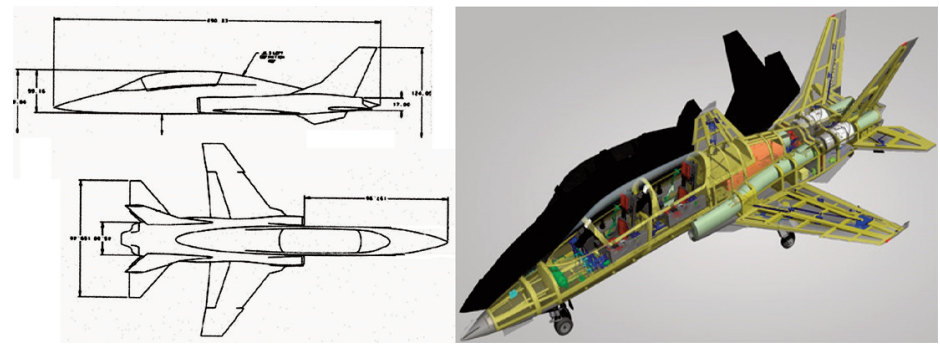

Fig. 1. ATG Javelin [9].

The aircraft is made according to the normal aerodynamic scheme. It is equipped with two bypass turbojet engines (TFE), retractable, two vertical tails. The AJT Javelin differs from existing military JTA in that weapons cannot be mounted on it, which limits its scope and decreases maintenance costs. Combat training has been replaced by a simulation system. 
Peregrine 600 - a training aircraft created by the US-based company Gulfstream Aerospace (Fig. 2). The aircraft is made according to the normal aerodynamic scheme, has a free-carrying swept wing, retractable tricycle landing gear with a nose strut, and is equipped with one turbojet bypass engine.

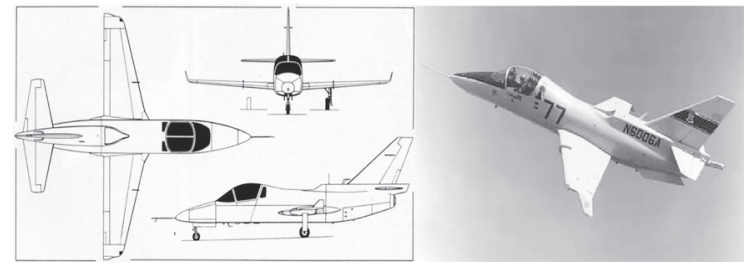

Fig. 2. Peregrine 600 [9].

EM-10 Bielik - training aircraft made according to the normal aerodynamic scheme (Fig. 3), designed to train military and civilian pilots. Represents a single-engine plane with a swept wing, two vertical tails and tricycle landing gear.

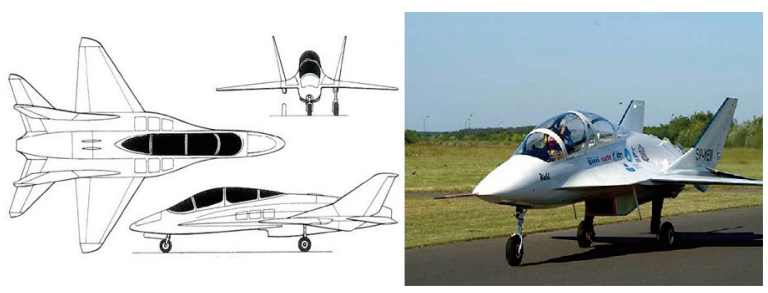

Fig. 3. EM-10 Bielik [9].

Ranger 2000 developed in accordance with the requirements of the US Armed Forces for a single training JPATS (Joint Primary Aircraft Training System) aircraft by Rockwell International in conjunction with Deutsche Aerospace (DASA) [2]. This aircraft is made according to the normal aerodynamic scheme and is equipped with one turbojet engine. The tail is T-shaped. Over the roots of the wing consoles, there are mounted air brakes (Fig. 4).

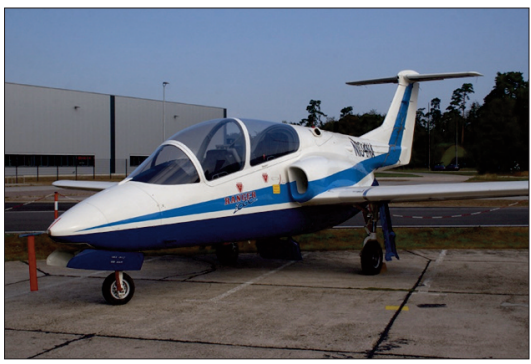

Fig. 4. Ranger 2000 [9].

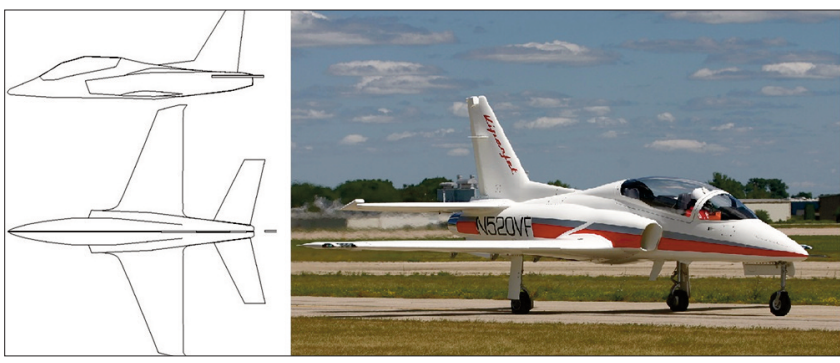

Fig. 5. Viper Jet [9].

Viper Jet - this light jet aircraft manufactured by Viper is a single-engine aircraft with a normal aerodynamic scheme, a monoplane with a low swept wing and a cockpit made according to the "tandem" scheme (Fig. 5). The air intakes are located on the sides of the fuselage. The aircraft is equipped with tricycle landing gear with a nose strut. Composite materials widely are used in its construction. 
Tab. 1. Statistical data for aircraft in the similarly purposed class.

\begin{tabular}{|c|c|c|c|c|c|c|c|}
\hline & The name of aircraft & $\begin{array}{c}\text { ATG } \\
\text { Javelin }\end{array}$ & $\begin{array}{l}\text { Peregrine } \\
600\end{array}$ & $\begin{array}{l}\text { EM-10 } \\
\text { Bielik }\end{array}$ & Ranger 2000 & Viper Jet & Designed \\
\hline \multirow{6}{*}{ 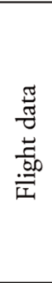 } & $V_{\max }, \mathrm{km} / \mathrm{h}$ & 975 & 730 & 1000 & 726 & 804 & 940 \\
\hline & $H_{\max }, \mathrm{m}$ & 13715 & 15000 & 15000 & 10668 & 13500 & 15000 \\
\hline & $V_{t-o}, \mathrm{~km} / \mathrm{h}$ & 195 & 210 & 180 & 180 & 175 & 220 \\
\hline & $R, \mathrm{~km}$ & 1111 & 1000 & 1250 & 1090 & 960 & 1250 \\
\hline & $L_{t-o}, \mathrm{~m}$ & 245 & 250 & 265 & 270 & 304 & 250 \\
\hline & $L_{\text {land }}, \mathrm{m}$ & 336 & 390 & 350 & 360 & 380 & 300 \\
\hline \multirow{7}{*}{ 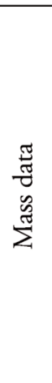 } & $m_{0}, \mathrm{~kg}$ & 2750 & 2685 & 2250 & 3250 & 2320 & 2264 \\
\hline & $m_{\text {empty }}, \mathrm{kg}$ & 1950 & 1884 & 1700 & 2400 & 1452 & 1279 \\
\hline & $m_{e q}, \mathrm{~kg}$ & 320 & 310 & 280 & 390 & 270 & 247 \\
\hline & $m_{l}, \mathrm{~kg}$ & 100 & 220 & 200 & 350 & 250 & 240 \\
\hline & $N_{c r}$ & 2 & 2 & 2 & 2 & 2 & 2 \\
\hline & $m_{f}, \operatorname{kg}\left(\overline{m_{f}}\right)$ & $850(0.31)$ & $\begin{array}{c}750 \\
(0.28)\end{array}$ & $850(0.38)$ & $920(0.28)$ & $802(0.35)$ & $\begin{array}{c}535 \\
(0.236) \\
\end{array}$ \\
\hline & $m_{a f}, \mathrm{~kg}$ & 780 & 760 & 690 & 970 & 675 & 1032 \\
\hline \multirow{4}{*}{$\begin{array}{l}\frac{\tilde{J}}{0} \\
\text { aे }\end{array}$} & $\begin{array}{c}\text { Number and type of } \\
\text { engine }\end{array}$ & $\begin{array}{c}\text { 2xTFE } \\
\text { Williams } \\
\text { FJ33-4- } \\
17 \mathrm{M}\end{array}$ & $\begin{array}{c}\text { 1xTFE } \\
\text { P\&W } \\
\text { JT15D-4 }\end{array}$ & $\begin{array}{c}\text { 1xTFE } \\
\text { General } \\
\text { Electric } \\
\text { J-85 }\end{array}$ & $\begin{array}{c}\text { 1xTFE } \\
\text { P\&W } \\
\text { JT15D-5 }\end{array}$ & $\begin{array}{c}\text { 1xTFE } \\
\text { General } \\
\text { Electric J-85 }\end{array}$ & $\begin{array}{l}1 \times T F E \\
\text { AI-222 }\end{array}$ \\
\hline & $P_{0}, \mathrm{kN}$ & $2 \times 7.60$ & 11.12 & 13.5 & 14.19 & 13.5 & 17.2 \\
\hline & $m_{e n}, \mathrm{~kg}$ & 140 & 261 & 280 & 261 & 280 & 350 \\
\hline & $C_{p}, \mathrm{~kg} / \mathrm{daH} \cdot \mathrm{h}$ & 0.54 & 0.66 & 0.97 & 0.72 & 0.97 & 0.6 \\
\hline \multirow{9}{*}{ 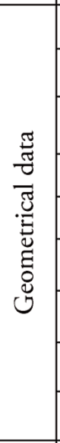 } & $S, \mathrm{~m}^{2}$ & 13 & 17 & 11.9 & 15.55 & 12 & 8.884 \\
\hline & $l, \mathrm{~m}$ & 7.65 & 10.5 & 6.6 & 10.46 & 7.8 & 7.3 \\
\hline & $\chi_{l . e, \mathrm{deg}}$ & 36.5 & 16 & 36 & 23 & 25 & -10 \\
\hline & $\lambda$ & 4.5 & 6.5 & 3.7 & 7 & 5 & 6 \\
\hline & $\eta$ & 4 & 2.4 & 4 & 5.2 & 3.5 & 2 \\
\hline & $D_{\text {fus }}, \mathrm{m}^{2}$ & 1.44 & 2.2 & 1.11 & 2.15 & 0.98 & 1.32 \\
\hline & $L_{\text {fus }}, \mathrm{m}$ & 11.8 & 11.68 & 9 & 7.85 & 7.8 & 8.87 \\
\hline & $\bar{S}_{G T}$ & 0.25 & 0.27 & 0.21 & 0.16 & 0.31 & 0.18 \\
\hline & $\bar{S}_{V T}$ & 0.38 & 0.18 & 0.29 & 0.20 & 0.39 & 0.3 \\
\hline \multirow{4}{*}{ 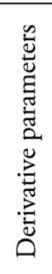 } & $\begin{array}{c}p_{0}=m_{0} \cdot g / 10 S, \\
\mathrm{daN} / \mathrm{m}^{2}\end{array}$ & 207.5 & 154.9 & 185.5 & 205 & 190 & 250 \\
\hline & $t_{0}=P_{0} / m_{0} \cdot g$ & 0.564 & 0.422 & 0.612 & 0.404 & 0.593 & 0.77 \\
\hline & $\begin{array}{c}\gamma_{0}=m_{e n} \cdot g / P_{0} \\
\mathrm{~kg} / \mathrm{daN}^{2}\end{array}$ & 0.181 & 0.23 & 0.203 & 0.18 & 0.203 & 0.194 \\
\hline & $K_{l}=m_{l} / m_{0}$ & 0.036 & 0.082 & 0.089 & 0.108 & 0.10 & 0.106 \\
\hline
\end{tabular}


Tab. 2. The main parameters for JTA.

\begin{tabular}{|c|c|c|c|c|c|c|c|c|c|}
\hline$\lambda$ & $\chi_{l . e}, \mathrm{deg}$ & $\eta$ & $\bar{c}$ & $\overline{b_{f}}$ & $\delta_{f}$ & $\overline{S_{e}}$ & $\lambda_{G T}$ & $D_{f}, \mathrm{~m}$ & $L_{f}, \mathrm{~m}$ \\
\hline 6 & -10 & 2 & 0.09 & 0.3 & $14 / 30$ & 0.057 & 6.72 & 1.32 & 8.87 \\
\hline$\overline{S_{G T}}$ & $\overline{S_{V T}}$ & $\lambda_{f}$ & $\lambda_{V T}$ & $\chi_{G T}, \mathrm{deg}$ & $\chi_{V T}, \mathrm{deg}$ & $\bar{c}_{G T}$ & $\bar{c}_{V T}$ & $\eta_{G T}$ & $\eta_{V T}$ \\
\hline 0.18 & 0.3 & 3.2 & 1.8 & 24 & 40 & 0.09 & 0.09 & 2.1 & 4.5 \\
\hline
\end{tabular}

$\begin{array}{ll}\text { Hereinafter } & \lambda=l^{2} / S-\text { wing aspect ratio (tail); } \\ & \chi-\text { wing sweep angle (tail); } \\ & \eta=b_{0} / b_{t}-\text { wing taper ratio (tail); } \\ & \bar{c}=c / b-\text { airfoil thickness ratio; } \\ & \overline{b_{f}}=b_{f} / b_{0}-\text { flap reference chord; } \\ & \delta_{f}-\text { flap deflection angles; } \\ & \bar{S}-\text { relative area. }\end{array}$

\section{Choice of aerodynamic layout of the aircraft}

The aerodynamic layout of an aircraft consists of the relative positioning of its various parts, their shape and size. Taken together, these factors determine the appearance of the aircraft and provide the specified aerodynamic characteristics, while solving the problem of optimal linkage with the overall layout (location of the powerplant, cargo, equipment and weapons in the selected load-carrying structure).

For training aircraft, it is advisable to have a normal aerodynamic scheme, which has become the most common. This is most convenient from the point of view of the pilot's "habituation" when switching to a new type of aircraft of the same scheme (giving the overwhelming predominance of aircraft of the normal scheme). Moreover, the normal aerodynamic scheme best meets the set of requirements for manned aircraft in terms of stability, controllability, flight safety and other flight characteristics. Thanks to the developed tail part of the fuselage, the necessary longitudinal and track stability and controllability can be provided without difficulty. Another main advantage of this scheme is that in the main flight modes, the horizontal tail has smaller angles of attack than the wing. Flow failure on the horizontal tail occurs at greater angles of attack than on the wing, or does not occur at all. The tail also does not affect the flow in front of the wing. The normal aerodynamic scheme offers good possibilities of longitudinal balancing of the aircraft with any means of wing mechanization used to improve the takeoff and landing characteristics of the aircraft [5].

The main disadvantage of this scheme, on the other hand, consists in the increased balancing losses compared to the "duck" scheme. They can be reduced by using a destabilizer, i.e. a combined scheme. The tail in the normal scheme also increases the drag and the total mass of the aircraft structure as compared to other schemes [5].

\section{Cockpit layout}

Positioning the two-person crew in the "tandem" configuration is not the most optimal from the point of view of cadet training, but such a scheme does have a number of other advantages: first and foremost, a gain in mass as compared to the "row" configuration of crew seating; secondly, noticeably less drag; and third, less radar visibility. However, given the very small size of the aircraft, this configuration of the crew creates a certain problem in terms of wing location. 
3. Choice of wing location relative to the fuselage

The wing is placed in the middle of the fuselage. This layout has the following advantages:

- reduced interference resistance [5];

- the ability to situate cargo compartments in the lower part of the fuselage.

4. Choice of external wingform

The wing of the aircraft has a forward sweep, with a sweep angle along the line of 0.25 chord $\chi_{0.25}=-13^{\circ}$. Such alignment conditions make it advisable to use a reverse sweep wing. In addition, the reverse sweep wing has a number of significant advantages:

- Maneuverability characteristics are higher at large angles of attack, as in these modes the reverse sweep wing is more important $c_{L}$ (Fig. 6).

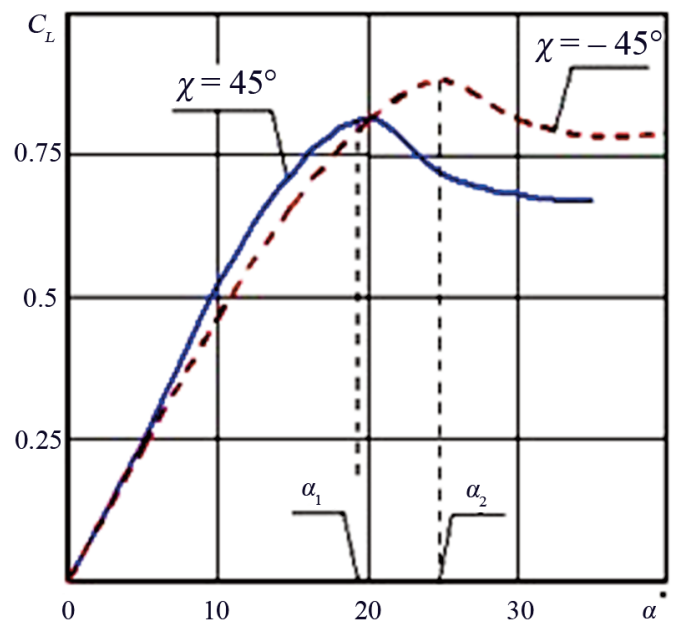

Fig. 6. Comparison of dependencies $C_{L}(\alpha)$ forward swept and swept wing [11].

- The probability of aircraft failure in a spin is lower.

- There are more options for different layout solutions, as the center of the wing is behind the center of mass of the aircraft.

- The flow failure zone is moved from the end of the wing console to its root (Fig. 7). This is due to the fact that the longitudinal component of the speed is directed from the wing console to its root. The thickness of the boundary layer will increase in the root of the wing, which will cause an earlier disruption of the flow in this area. The ends the consoles are streamlined without failure; therefore, this phenomenon maintains transverse and track stability at large angles of attack.

The main disadvantage of forward swept wings, on the other hand, is the lower values of the critical divergence rate than that of straight sweep wings [5].

In the front part of the wing there is an inflow, which is a small triangular wing located directly in front of the wing, which significantly improves the aerodynamic characteristics of the wing of the aircraft [5]. At subsonic flight speeds, the addition of such an inflow essentially does not alter the lift properties of the original wing at small angles of attack (less than 5-10 degrees). However, with a further increase in the angle of attack, the influx leads to an increase in the maximum coefficient of lift, an increase in lift, and a significant increase in the critical angle of attack. This phenomenon is due to the complex detachable transverse flow around the leading edges of the inflow and the formation of intense stable vortex systems, which create additional vacuum on the upper surface of the wing. Improvement of the lift properties of 
the wing at large angles of attack in the presence of inflows increases the maneuverability characteristics of the aircraft [5].
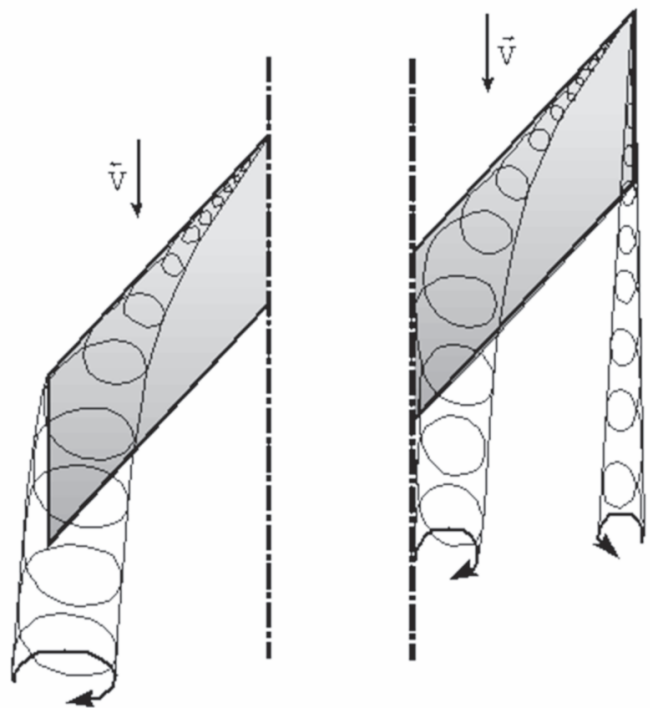

Fig. 7. Features of wing flow $\chi$ l.e $>0$ and $\chi$ l.e $<0$ [11].

\section{Choice of tail scheme}

The swept stabilizer is located in the tail of the fuselage. The vertical tail (VT) has two fins, as in the process of their training pilots must perform spins. The advantage of such tail is that when making a spin, one of the two fins is in undisturbed flow. This increases the efficiency of the rudder on it and facilitates bringing the aircraft out of the spin [5]. In addition, the vortices formed by inflows boost the efficiency of the vertical tail at large angles of attack. The fins are located at an angle to the vertical plane of symmetry of the fuselage, which allows them to be brought out of the aerodynamic shadow of the fuselage at large angles of attack.

\section{Selection of the scheme of take-off and landing devices}

A tricycle chassis scheme with a nose support is advisable for such a training jet design, as such a chassis scheme ensures: stable movement of the aircraft on the airfield; no impact of the jet of gases coming out of the engine on the surface of the aerodrome during parking and movement of the aircraft; the possibility of obtaining take-off and landing positions of the aircraft without touching elements of the airframe for the surface of the aerodrome [5]. In addition, the selected landing gear scheme facilitates the piloting of the aircraft during takeoff and landing, which is most relevant for training aircraft.

\section{Choice of powerplant}

For reasons of ease of piloting, maintenance and cost reduction, we propose to equip the training aircraft with one turbojet engine. One engine as the powerplant provides for reduced size, considerable decrease in design weight, reduced frontal resistance, etc.

In favor of choosing a single-engine powerplant scheme, we present the following arguments. First, the level of modern technology allows fairly reliable models of aircraft engines to be created with an extremely low probability of failure. Second, the statistics of accidents due to engine failure are extremely marginal. Thirdly, in the current economic conditions, the program of creating a single-engine TCB is much cheaper. Notably, there are many models of aircraft built on a single-engine scheme and successfully operated. These include the L-39 and L-59 (Czech Republic), the L-45 and F-16 (USA), the Hawk (England), the Alfa Jet (France-Germany), the Mirage 2000 (France) and others. Moreover, 
the location of the single engine in the fuselage has a number of advantages: the drag of the aircraft is reduced, an aerodynamically clean wing is provided, and the noise in the cockpit is reduced.

The scheme of our aircraft design is shown in Fig. 8.

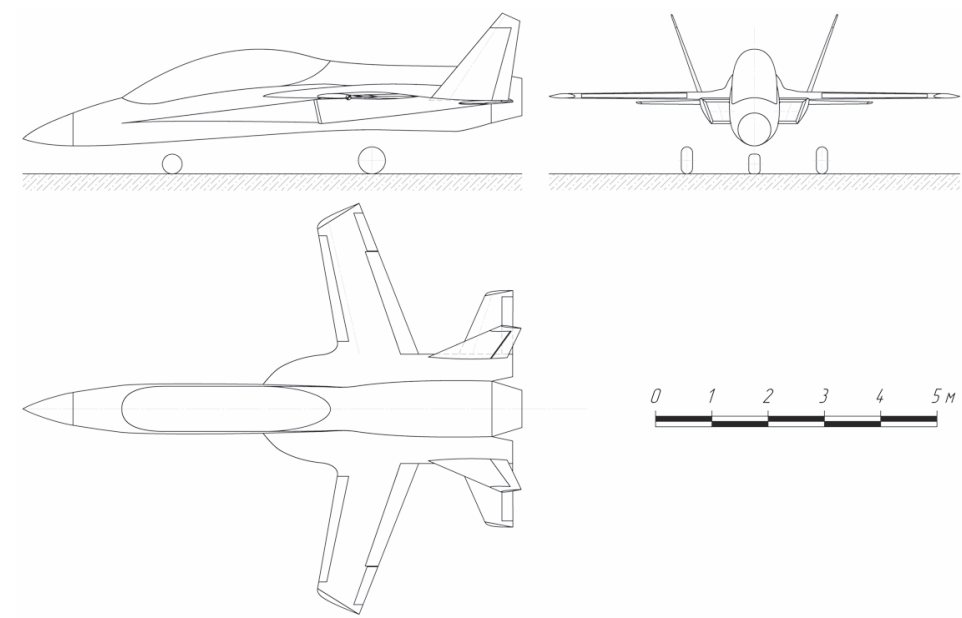

Fig. 8. Scheme of the designed aircraft.

Calculation of aircraft mass in three approximations

Determination of the mass of an aircraft design can begin only after the choice of the overall scheme for the aircraft (Fig. 8), as the mass of its components largely depends on their external shapes, sizes and relative positions. Here we present the results of our calculations of the takeoff mass of the aircraft in three approximations, where the criterion of optimality is the minimum takeoff mass while ensuring the basic tactical and technical requirements [3].

1. Determination of the take-off mass of the aircraft in the zero approximation

The take-off mass of the aircraft in the zeroth approximation is determined by the formula [5]

$m_{0}^{0}=\frac{m_{l}+m_{s . l}}{1-\left(\bar{m}_{a f}+\bar{m}_{p p}+\bar{m}_{f}+\bar{m}_{e q . c t r l}\right)}$

where $m_{0}^{0}$ - the take-off mass of the aircraft in the zeroth approximation;

$m_{l}=240 \mathrm{~kg}-$ load (e.g. video equipment for aerial surveillance tasks);

$\bar{m}_{a f}=0.27-$ the relative weight of the structure;

$\bar{m}_{p p}=0.18-$ the relative mass of the powerplant;

$\bar{m}_{f}=0.25$ - relative mass of fuel;

$\bar{m}_{\text {eq.ctrl }}=0.11-$ relative weight of equipment and control.

The mass of the service load, which includes the mass of the crew, oil, technical fluids consumed in flight, first aid kit, rescue equipment, is determined as follows:

$m_{s . l}=80 \cdot n_{c r}+\Delta m_{e . s}$ 
where $n_{c r}=2-$ number of crew members, pers.;

$\Delta_{\text {me.s }}$ - weight of equipment and service load, kg;

$m_{\text {s.l }}=80 \cdot 2+50=210 \mathrm{~kg}$.

Then [5]

$m_{0}^{0}=\frac{240+210}{1-(0.27+0.18+0.25+0.11)}=2368.4$

\section{Determination of takeoff mass in the first approximation}

The calculation method used involves determining the minimum take-off mass of the aircraft depending on the specific load on the wing $p$ and the aspect ratio of the wing $\lambda$. The take-off mass of the aircraft in the first approximation [5]:

$m_{0}^{I}=\frac{m_{l}+m_{s . l}}{1-\left(\bar{m}_{a f}+\bar{m}_{p p}+\bar{m}_{f}+\bar{m}_{e q . c t r l}\right)}$

where $\bar{m}_{a f}, \bar{m}_{p p}, \bar{m}_{f}$ - the relative masses of the airframe, powerplant and fuel, respectively, which are to be determined depending on the main power, mass and geometric parameters of the aircraft and specified in the requirements height, speed, range, take-off length, landing length, etc.

3. Calculation of the takeoff mass in the second approximation

When calculating the take-off mass of the second approximation, the values of the mass of the airframe and the mass of the equipment are specified.

The take-off mass of the aircraft in the second approximation is determined by the formula [5]:

$m_{0}^{I I}=\frac{m_{l}+m_{s . l}+m_{e q . c t r l}+m_{w}+m_{f u s}+m_{t}+m_{l . g}}{1-\left(\bar{m}_{p p}+\bar{m}_{f}\right)}$

where $m_{w}$ - wing weight, kg; $m_{f u s}-$ fuselage weight, kg;

$m_{t}-$ tail weight, kg; $m_{l . g}-$ landing gear weight, $\mathrm{kg}$.

Here the weights $m_{w}, m_{t}, \bar{m}_{p p}$ and $\bar{m}_{f}$ are functions of the specific load on the wing, so the takeoff mass of the aircraft in the second approximation is a function of p, i.e. $m_{0}^{I I}=f(p)$ (Fig. 8).

Selection of the engine and check of run length before take-off

We determined the values of the optimal specific load on the wing, which correspond to the minimum mass of the aircraft, by taking into account the limitations on the landing speed and normal overload when flying in a turbulent atmosphere. Using the data of calculations of the maximum required powerto-weight ratio for the corresponding type of aircraft, for the optimal specific load on the wing determine the amount of required thrust $t_{0}^{*}$ (Fig. 9). The calculated power-to-weight ratio of one engine is now found by the formula

$$
P_{0}=\frac{t_{0}^{*} \cdot m_{0}^{I I} \cdot g}{10 \cdot n_{e n}}
$$

where $t_{0}^{*}=0.612$ - power-to-weight ratio; $m_{0}^{I I}=2270 \mathrm{~kg}$ - the take-off mass of the aircraft in the second approximation; $n_{e n}=1-$ number of engines. 
Then

$P_{0}=\frac{0.612 \cdot 2270 \cdot 9.81}{10 \cdot 1}=13.64 \mathrm{kH}$.

AI-222 engine was selected. The main characteristics of the engine:

$p_{0}=25 \mathrm{kH}-$ starting thrust; $m_{\text {en }}=350 \mathrm{~kg}$ - engine weight;

$c_{p}=0.65 \mathrm{~kg} / \mathrm{kgf} \cdot \mathrm{h}-$ specific fuel consumption; $y=1.18$ - bypass ratio;

$l_{\text {en }}=1.96 \mathrm{~m}$ - engine length; $d_{e n}=0.896 \mathrm{~m}$ - engine diameter.

The test calculation of the run length before take-off of the aircraft with the selected engine is performed according to the formula [5]

$$
L_{p}=\frac{0.832 \cdot p}{C_{L t-o}\left[\frac{\xi_{V} \cdot \xi_{H} \cdot \xi_{i n t} \cdot \xi_{t h r} \cdot P_{0} \cdot n_{e n}}{m_{0}^{I I} \cdot g}-\frac{1}{3}\left(\frac{1}{K_{t-o}}+2 \cdot f\right)\right]}
$$

where $C_{L t-o}=1.353$ - the coefficient of lift of the wing during takeoff; $\xi_{V}, \xi_{H}, \xi_{t-O}, \xi_{t h r}-$ coefficients that take into account the change in thrust (power) depending on the magnitude of the takeoff speed, the height of the takeoff aerodrome, losses in the air intakes, the degree of throttling of the engines; $f=0.02$ - coefficient of friction; $K_{t-o}=10.5$ - the lift to drag ratio of the aircraft at takeoff.
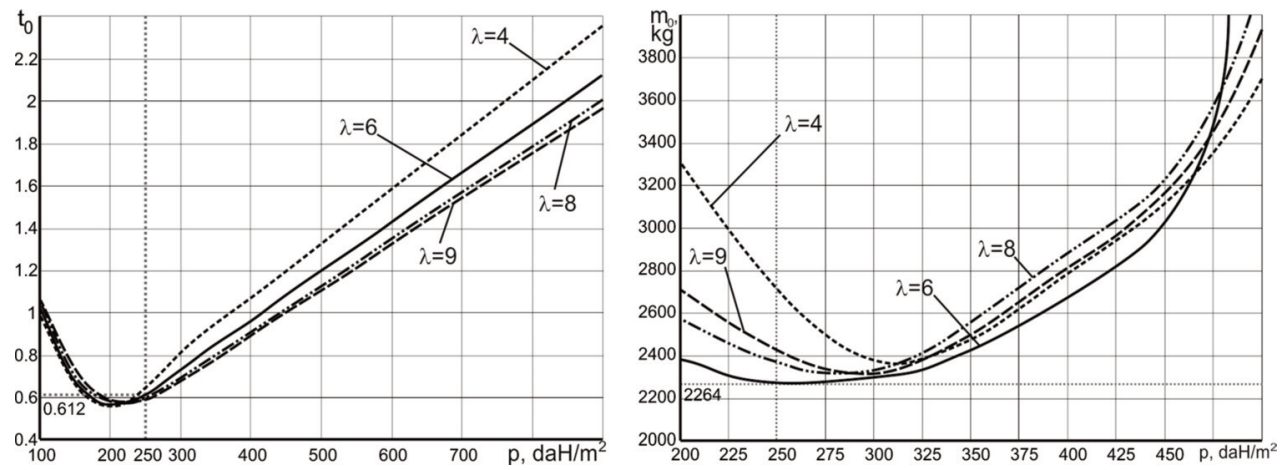

Fig. 9. Dependence of power-to-weight ratio and takeoff mass of the aircraft on the wing aspect ratio and the specific load on the wing.

Let us define the coefficients $\xi[5]$ :

$\xi_{H}=1 ; \xi_{t-o}=0.96 ; \xi_{t h r}=1$;

$\xi_{V}=1-\left(0.5+0.113 \cdot y-0.0069 \cdot y^{2}\right) \cdot M+(0.6+0.01 \cdot y) \cdot M^{2}=$

$=1-\left(0.5+0.113 \cdot 2.2-0.0069 \cdot 2.2^{2}\right) \cdot 0.17+(0.6+0.01 \cdot 2.2) \cdot 0.17^{2}=0.9$

Then [5]

$L_{p}=\frac{0.832 \cdot 250}{1.353\left[\frac{0.9 \cdot 1 \cdot 0.96 \cdot 1 \cdot 25000 \cdot 1}{2270 \cdot 9.81}-\frac{1}{3}\left(\frac{1}{10.5}+2 \cdot 0.02\right)\right]}=180 \mathrm{~m}$.

This engine provides the specified run length. 


\section{Calculation of the takeoff mass in the third approximation}

The essence of determining the takeoff mass of the aircraft in the third approximation is to clarify the mass of the powerplant and the mass of fuel. The initial data for the calculations are the results of the calculation in the previous sections. The take-off mass of the second approximation is taken as a basis $m_{0}^{I I}$.

\subsection{Determination of the mass of the powerplant}

To determine the mass of the powerplant, we use the formula

$m_{p p}=R^{\prime} \cdot m_{e n} \cdot n_{e n}$

where $n_{e n}$ - the number of engines installed on the aircraft;

$m_{\text {en }}-$ engine weight, $\mathrm{kg}$;

$R^{\prime}$ - a factor that takes into account the increase in the mass of the powerplant compared to the mass of the engine.

For aircraft with turbojets

$$
R^{\prime}=k_{1} \cdot\left(1+0.1 \cdot \frac{n_{\text {en.rev }}}{n_{\text {en }}}\right) \cdot\left[k_{a b}+\frac{k_{\text {int }}}{\gamma_{\text {en }}}\left(1.2+0.275 \cdot y^{0.75}\right)^{2}\right]
$$

where $k_{1}$ - a factor that takes into account the number of engines and the place of their installation on the aircraft; $k_{1}=0.95$ - one engine in the tail of the fuselage; $n_{\text {en.rev }}=0$ - the number of engines equipped with reverse thrust; $k_{a b}$-coefficient taking into account the presence of engine afterburner; $k_{a b}=1.0-$ coefficient for engines without afterburners; kint - a factor that takes into account the type of air intakes and engine nozzles; $k_{\text {int }}=0.0236-$ for flat long air intakes; $\gamma_{e n}=0.21 \mathrm{daH} / \mathrm{daH}-$ passport specific weight of the engine.

$$
R^{\prime}=0.93 \cdot\left(1+0.1 \cdot \frac{0}{1}\right) \cdot\left[1+\frac{0.0236}{0.21} \cdot\left(1.2+0.2752 \cdot 2.2^{0.75}\right)^{2}\right]=1.2 \text {. }
$$

Mass of the powerplant was calculated: $m_{p p}=1.2 \cdot 350 \cdot 1=420 \mathrm{~kg}$.

\subsection{Determination of fuel mass}

In the third approximation, the mass of fuel is determined by the formula

$$
m_{f}=m_{0}^{I I} \cdot \bar{m}_{f}^{I I}
$$

where $\bar{m}_{f}^{I I}$ - the relative mass of the fuel of the second approximation, taking into account the specific fuel consumption of the selected engine;

$$
\bar{m}_{f}^{I I}=\bar{m}_{f . H}+\bar{m}_{T . c r}+\bar{m}_{T . N}+\bar{m}_{T . d e s c}+\bar{m}_{T . R},
$$

where $\bar{m}_{f . H}$ - the relative mass of fuel that is consumed per set height; $\bar{m}_{f . c r}$ - the relative mass of fuel that is consumed in cruising flight; $\bar{m}_{f . N}$ - relative mass of fuel for navigation stock; $\bar{m}_{T \text {.desc }}-$ the relative mass of fuel that is spent on descent and landing; $\bar{m}_{T . R}$ - relative mass of remaining fuel which rest does not merge, $\bar{m}_{T . R}=0.006$. 
Finding the mass of fuel of the third approximation according to the above dependence (9):

$m_{f}=2270 \cdot 0.236=536 \mathrm{~kg}$.

\subsection{Calculation of takeoff mass in the third approximation}

The take-off mass of the aircraft in the third approximation is determined by the following equation:

$m_{0}^{I I I}=m_{l}+m_{s . l}+m_{e q . c t r l}+m_{w}+m_{f u s}+m_{t}+m_{l . g}+m_{p p}+m_{f}$

The value of the components of the takeoff mass is shown in Tab. 3 .

Tab. 3. Components of the takeoff mass

\begin{tabular}{|l|c|c|}
\hline Name & Designation & Value, $\mathrm{kg}$ \\
\hline Load weight & $m_{l}$ & 240 \\
\hline Service load weight & $m_{s . l}$ & 210 \\
\hline Equipment and control weight & $m_{\text {eq.ctrl. }}$ & 247 \\
\hline Wing weight & $m_{w}$ & 171 \\
\hline Fuselage weight & $m_{f u s}$ & 239 \\
\hline Tail weight & $m_{t}$ & 95 \\
\hline Landing gear weight & $m_{l . g}$ & 107 \\
\hline Powerplant weight & $m_{p p}$ & 420 \\
\hline Fuel weight & $m_{f}$ & 535 \\
\hline Takeoff weight & $m_{0}^{I I I}$ & 2264 \\
\hline
\end{tabular}

\section{RESULTS: THE TRAINING AIRCRAFT DESIGN}

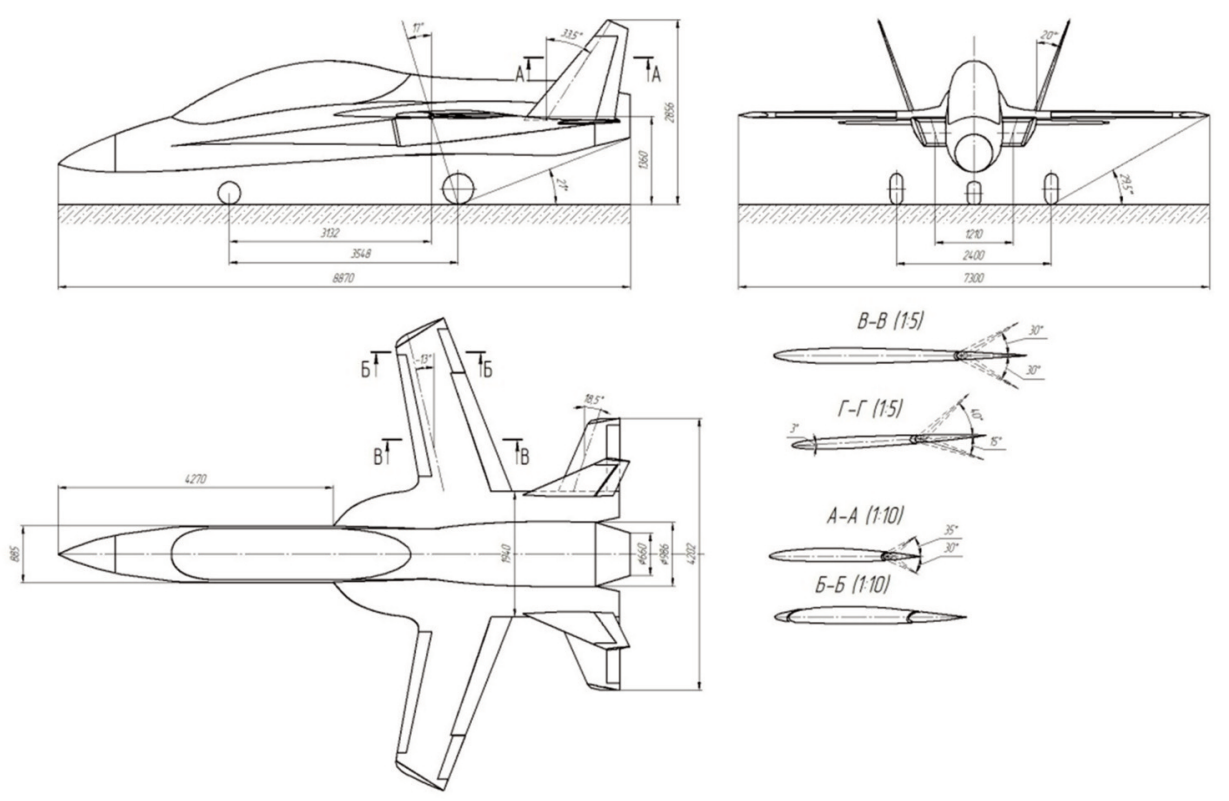

Fig. 10. Fragment of the general view of the training aircraft. 
After calculating the takeoff mass in the third approximation, we determined the geometric parameters of the designed aircraft. After calculating the alignment, a general view drawing of the training aircraft was developed (Fig. 10). Based on the general view drawing, with the help of the Siemens NX computer integrated system [10], we created the master geometry and layout model of the designed plane (Fig. 11, 12).

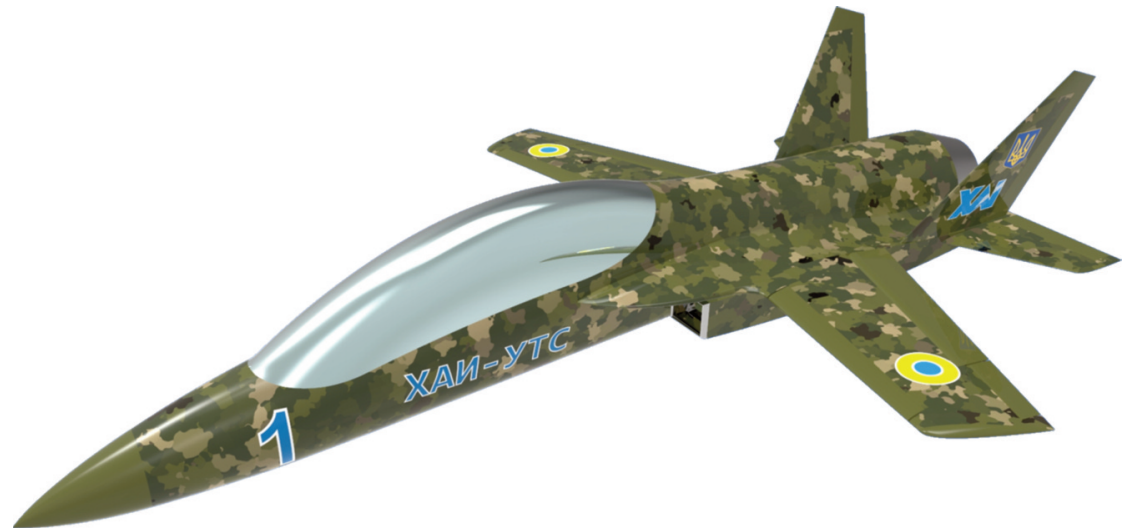

Fig. 11. Master geometry of the jet training aircraft.

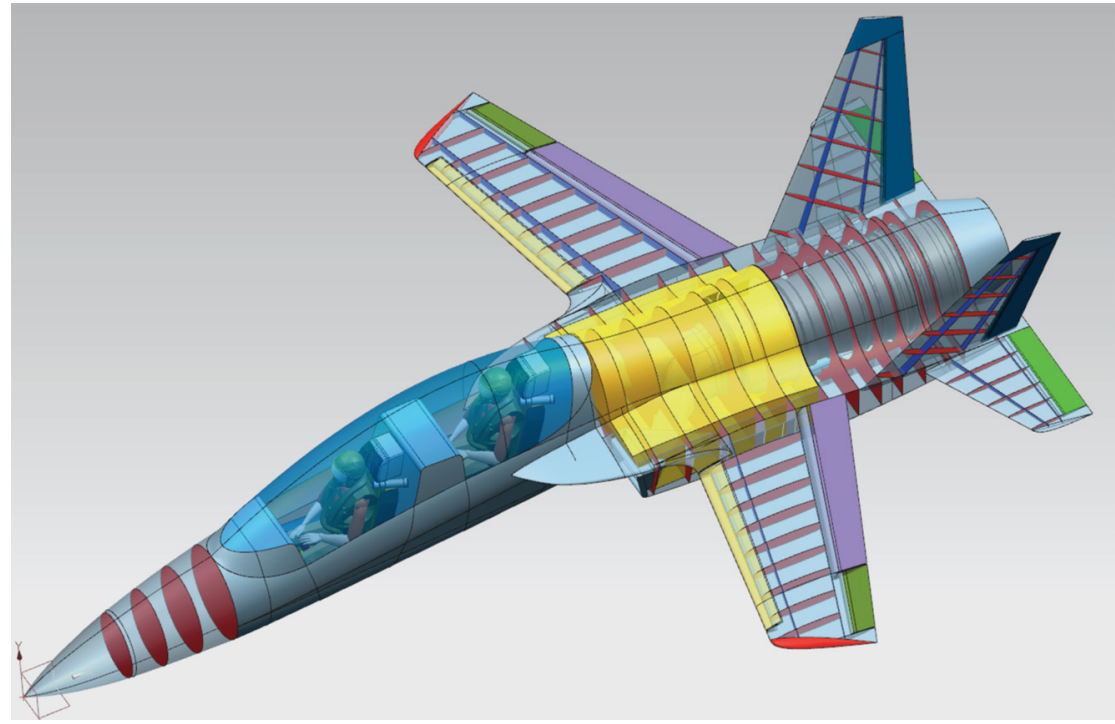

Fig. 12. JTA space distribution model.

\section{CONCLUSIONS}

This paper first presented a set of assumptions and requirements for a jet training aircraft (JTA). Next, we presented a statistical analysis of similarly-purposed planes and justified certain choices in the plane scheme. Based on the analysis of prototype aircraft schemes, a classic scheme with horizontal tail located behind the wing, two-fin vertical tail and retractable tricycle landing gear with a nose strut was selected. The take-off mass of the training aircraft was calculated, in three approximations, as $2264 \mathrm{~kg}$. Lastly, based on the calculated geometrical parameters, a general view of the aircraft and its master geometry were presented. 
The resulting preliminary design for a jet training aircraft (JTA) as developed and presented herein may serve as the basis for sketching and working designs, for further research on aerodynamics and structural strength, and for creating the documentation necessary for the subsequent manufacture of the training aircraft.

\section{REFERENCES}

[1] Badyagin A.A., Eger S.M., Mishin V.F. et al., 1972, Proektirovanie samoletov: ucheb. dlya studentov vuzov [Aircraft design: A textbook for university students]. 2nd ed. Moscow, Mashinostroenie.

[2] Eger S.M., Mishin V.F., Lisicin N.K. et al., 1983, Proektirovanie samoletov: ucheb. dlya vuzov [Aircraft design: A textbook for universities]. 3rd ed. revised, revised and extended. Moscow: Mashinostroenie.

[3] Akimov A.N., Vorob'ev V.V., Demchenko O.F. et al. 2005, Osobennosti proektirovaniya legkix uchebno-boevyx samoletov [Features of the design of light combat trainer aircraft], edited by N.N. Dolzhenkov and V.A. Podobedov. Moscow: Mashinostroenie / Mashinostroenie-Polet.

[4] Brahman T.R., 1984, Mnogokriterial'nost' i vybor al'ternativy v texnike [Multicriteria and choice of alternatives in engineering]. Moscow: Radio i Svyaz'.

[5] Balabuev P.V., Bychkov S.A., Grebenikov A.G. et al. 2003, Osnovy obshhego proektirovaniya samoletov s gazoturbinnymi dvigatelyami [Fundamentals of General Design of Aircraft with Gas Turbine Engines], Kharkiv: Kharkiv Aviation Institute - National Aerospace University.

[6] Semenchin V.A., 2003, Aehrodinamika i dinamika poleta [Flight aerodynamics and dynamics]. Kharkiv: Kharkiv Aviation Institute - National Aerospace University.

[7] Kiva D.S., 2014, Nauchnye osnovy integrirovannogo proektirovaniya samoletov transportnoj kategorii [Scientific bases of integrated design of transport category airplanes], part 3, Kharkiv: Kharkiv Aviation Institute - National Aerospace University.

[8] Yeger S.M., Liseytseitsev N.K., Samoilovich O.S.,1986, Osnovy avtomatizirovannogo proektirovaniya samoletov [Fundamentals of computer-aided design of aircraft] / Moscow: Mashinostroenie.

[9] Jane's All the World's Aircraft 2004-2005. Jane's Information Group, 2005.

[10] Goncharov P.S. et al. 2010, NX dlya konstruktora-mashinostroitelya [NX for mechanical engineers], Moscow: DMK Press.

[11] Eremenko S.M., 2019, Aehrodinamika letatel'nyx apparatov [Aerodynamics of flying vehicles]: Kharkiv: Ministry of Education and Science of Ukraine, Zhukovskiy National Aerospace University, Karkiv Aviation Institute - National Aerospace University.

[12] Akimov A.N., Vorob'ev V.V., Demchenko O.F. et al. 2005, Osobennosti proektirovaniya legkix uchebno-boevyx samoletov [Features of the design of light combat trainer aircraft], edited by N.N. Dolzhenkov and V.A. Podobedov. Moscow: Mashinostroenie / Mashinostroenie-Polet.

[13] Brahman T.R., 1984, Mnogokriterial'nost' i vybor al'ternativy v texnike [Multicriteriality and alternative choice in engineering] Moscow: Radio i svyaz'.

[14] Nicolin I., Barsan D. et al., 2018, "Analysis of requirements for new generation school and training aircraft. Determination of general characteristics for IAR 99NG aircraft" Code: PN 18010401 , INCAS. "Elie Carafoli” National Institute for Aerospace Research, Bucharest.

[15] Freed D, 2017, "Meet the Jets Competing to Become the Next Air Force Trainer," Air \& Space Magazine, (https://www.airspacemag.com/military-aviation/t-38-replacements-180967111/).

[16] Kandemir O., Gomec F.S., 2020, “Aerodynamic Nose Optimization of a Jet Trainer Aircraft," AIAA AVIATION 2020 FORUM. AIAA 2020-3121. 


\title{
WSTĘPNY PROJEKT ODRZUTOWEGO SAMOLOTU SZKOLENIOWEGO
}

\begin{abstract}
Abstrakt
W pracy przedstawiono wyniki projektu opracowania wstępnej konstrukcji odrzutowego samolotu szkoleniowego (JTP) z dwuosobową załogą, z podstawową wersją przeznaczoną do szkolenia kadetów. Rozważono założenia i wymagania stawiane nowemu samolotowi oraz dokonano przeglądu parametrów istniejących konstrukcji samolotów w klasie o podobnym przeznaczeniu. Podano argumenty przemawiające za określonymi wyborami konstrukcyjnymi, dotyczącymi układu samolotu, konfiguracji kabiny pilota, położenia i kształtu skrzydeł, schematu ogona oraz zespołu napędowego. Obliczono, że projektowany samolot będzie miał maksymalną prędkość lotu $940 \mathrm{~km} / \mathrm{h}$, prędkość wznoszenia na poziomie ziemi $100 \mathrm{~m} / \mathrm{s}$ i zasięg $1130 \mathrm{~km}$. Masę startową samolotu obliczono, w trzech przybliżeniach, na $2264 \mathrm{~kg}$. $\mathrm{Na}$ zakończenie przedstawiono parametry geometryczne opracowanego samolotu treningowego, widok ogólny oraz geometrię.
\end{abstract}

Słowa kluczowe: odrzutowy samolot szkolno-treningowy, osiąi, masa startowa, schemat, geometria samolotu 